「農業の繊維・高分子」特集

\title{
農業の変化と䋐維・高分子化合物 野菜の施設園芸を中心として一一
}

西 貞夫

\section{1. 農業と高分子化合物}

人類が、植物を栽培し, 動物を飼育して, 生活に必要 な資材を生産する産業を「農業」と呼ぶならば，その歴 史は極めて古く，その間に多種多様な生産用資材が用い られ，現在でいうところの「天然高分子化合物」が，幅 広く用いられてきたであろうことは申寸までもない。し かしながら, 経験則的・篤農的技術を脱却した, 科学的 産業としての近代農業は, 西欧では産業革命以後, わが 国の場合は，西欧文物の導入が積極的に進められた，明 治維新以後に始まったとされている。わが国の場合，国 立の農業試験場が東京・西ヶ原に設立されたのは明治 26 (1938) 年で, 本平成 5 年で満100年を数えるが、昭和 30年代の始めまで, 専ら水田稲作を主体に進められて来 たことは広く知られている。この間に, $10 \mathrm{a}$ 当りのコメ の収量は, 明治初期の $200 \mathrm{~kg}$ から昭和50年代半ばには $500 \mathrm{~kg}$ に達し, 今や生産過剩の時代を迎えるに至ったが、 この様な生産力の向上は, 明治・大正かけての農薬（殺 菌・殺虫郕) の利用, 大正・昭和にかけての化学肥料の 普及等, 化学物質の利用に負う所が極めて大きく, 同時 に,これらに支えられた品種改良の成果が、日本農業を 発展させてきたということができる。

農業生産の発展は，その特性上技能的技術の開発によ る面が極めて大きく，土壤・肥料や植物生理，あるいは バイテクを含む遺伝・育種などは, 一部を除いて, 自ら のいわゆる基碟（的）研究の成果に基づく場面は限られ, 専ら周辺科(化)学の進歩, 周辺産業の成果に支えられて きたが, 特に高分子化学の成果による例は極めて多く, 枚挙にいとまがないといって良い状態であって，稻作農 業一辺倒から脱却し, 各種農産物への転換が求められる に至った現在，その傾向は一段と高まりつつあると考え られる。

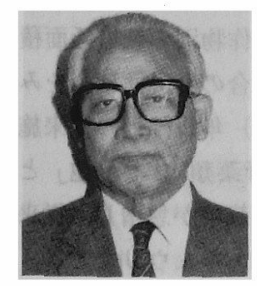

Fibers and Polymer Compounds in the Change of Agriculture

- Focusing on the Protected Horticulture of Vegetables-

筆者紹介 SADAO NISHI

Japan Greenhouse Horticulture Association

社団法人 日本施設園芸協会 会長, 農学博士

筆者は、野菜育種が御専門であり，農林大臣賞，科学技術庁長官賞を始めとする多数の賞を受けられて いる。趣味は, 読書, 音楽鑑賞（クラシック）などである。

本稿は、農業と䄉維・高分子化合物について, 歴史的背景も混えて概説して頂いた。
第二次世界大戦後に拉ける高分子化学の進歩で生まれ た多数の合成高分子化合物は，それぞれの特性を生かし て, 合成樹脂 (プラスチック), 合成䄉維, 合成ゴム, 塗料，接着剤などを生み，更に合成皮革，合成紙，合成 木材などの形で，広く農業生産を裨益してきたが，これ らの中で最も顕著な産業的効果を挙げたものの一つとし て、フィルムを主とするプラスチック類の「施設園芸」 への利用がある。

施設園芸とは，木・金属製の組骨みに被覆資材を貼り 付け, 外界の気象条件から植（作）物を隔離・保護し, 生育に不適当な時期（主として低温期）に出荷する栽培 法を指している。栽培法としては元禄時代の野菜栽培に 端を発すると云われるが, 近代的のそれは, 明治の中頃 ヨーロッパ風のブドウのガラス室栽培導入によって, わ が国に紹介された。それ以前にも温泉熱利用が可能な地 方では, 古くから油紙を張った障子枠利用による野菜栽 培が行われていたが, それらは高等園芸·促成栽培・不時 栽培などと呼ばれ, 主として特殊階級や高級料亭などで の用に供せられていた。第二次大戦後にアメリカ軍が, 南方で雨衣用などに用いたプラスチックフィルムをわが 国に紹介し，それを前述の油紙の代用にする試みが，昭 和26 (1951) 年に, 当時の農林省・園芸試験場で試みられ た。当初は素材としての適性を欠くためのトラブルが多 く，利用が淮まなかったが，やがてメーカーの努力によ る可塑㣚の開発などにより, フィルムとしての性能改良 が進められ，数年を出でずして油紙を淩ぐ被覆資材とし ての利用が定着した。やがてトンネル・八ウス用等, 骨 材の改良も進んで, 昭和 20 年代末までに, 現在見る様な, プラスチックフィルム利用栽培の各種租型が完成し, 「ビニールハウス栽培 (法)」と呼ばれる様になった。 
更に当初は不安定だった暖房方法が，昭和30年代に入る と, 工場用温風暖房機の導入 (ダクト利用) で解決され， $こ の$ 样な被覆資材機器利用の栽培方式を,「施設園芸」 と呼ぶ慣習が、昭和 35 - 6 年頃に広く定着するに至った。 施設園芸の発展, 即方高分子化合物利用の, 産業的意 義が顥著であると述べたのは，次の様な理由によってい る。わが国の野菜生産は，南北に長いという立地条件や 気象の多梯性に助けられ, 極めて多数の野菜 (古く 100 種類といわれ，最近は180を数える)を用いて行われて いるが，明治・大正以来常に年 2 回に及ぶ「野菜欠乏 期」に恼まされて来た。「端境期（はざかいき）と呼ば れる，2月と8月の久そ期がそれで，前者は低温による 作付の不能, 後者は南洋にも似るとされる高温が原因で あった。大部分の国民は，冬季は漬物と囲い物と呼ばれ る，ダイコン・ハタサイ・キャベッの貯蔵物のみですご し，夏はうら成りの野菜で秋野菜の出荷を待つという食 生活を強いられた。これに対して、プラスキックフィル 么利用の施設 (ハウス) 栽培が, 昭和26 (1951) 年以降 に始まり，品種改良の成果と相俟って，昭和30年代半ば までには，冬季の野菜欠乏 (端境期) の解消に成功し， 国民の食生活に大きく寄与するに至っした。また夏季の 野菜久之は，昭和30年代に入っての所得倍增計画・列島 改造論に始まり，オリンピックに向けて行われた全国的 な交通網の整備によって, 高冷（山）地や東北等冷涼地 からの野菜出荷が可能になったことによって, 解消され た。その様にして二つの端境期が解消され，野菜の周年 にわたる生産と出荷が，全国的に可能になったのは，昭 和35〜7年頃のことである。冬期の施設野菜生産はいう までもなく，夏期にあっても，世界有数の多雨地帯であ るわが国の, 野菜生産を安定させているのは，高分子化 合物であるプラスチック類の降水をしゃ断する働きにほ かならない。

\section{3. 施設園芸の現状}

農水省の調査によると, 平成 3 (1991）年度の園芸施 設（ガラス室・八ウス）の設置面棈は約 5 万1000haで， その区別扩よび園芸作物別の内訳は，図 1．2 に示すと おりである。両図に示されるように，わが国の施設園芸 は，現状にあっては，プラスチックハウス（特に簡易な パイプハウス）が主体であり，作物としては，压倒的に 野菜で占められていることがわかる。施設本来の機能を 十分に発揮させ，また農業者の老令化・後継者不足对策 等を考慮した付带施設の增加（自動制御など）傾向を考 えると，将来的にはオランダ・イギリスの様な、ガラス 温室がすぐれているともいえるが，わが国の場合は，発 足時の経済事情や台風対策・夏期の高温等（使用不能）

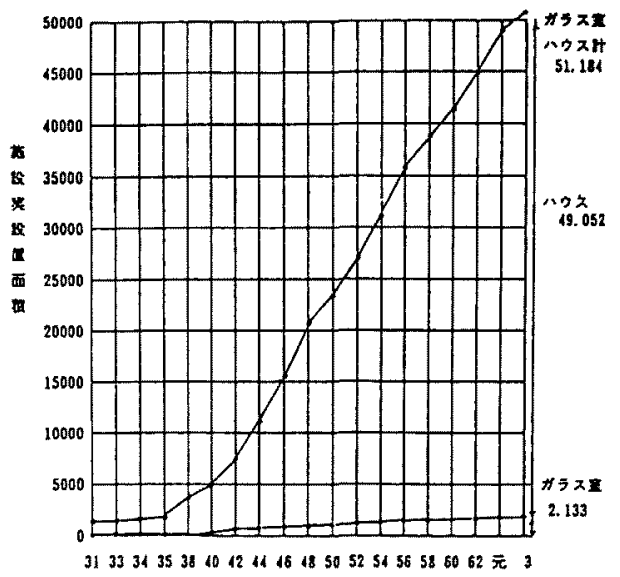

図 1 施設栽培用設置実面積の推移（単位：ha）

資料：農林水隡省食品流通局「ガラス室・ハウス等の設 置状況」

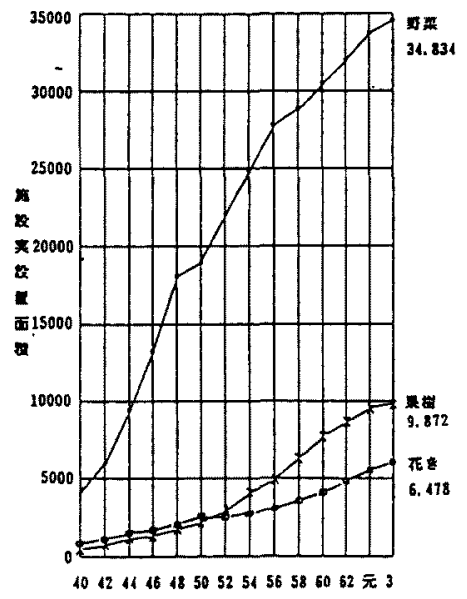

因 2 作物別施設実設置面積の推移（単位：ha）

資料：農林水险省食品流通局「ガラス堂・ハウス等の設 置状況」

の気象的立地を反映して、ブラスチックフィルムの利用 となった。また野菜の作付けが多いのは，基本的に施設 が, 低温期の野菜供給確保を目的としていたこと等に発 しているが，近年は図 2 に見る様に，花き・果樹類の施 設栽培の伸びが著しい。しかしそれらも，現状では大部 分がプラスチックフィルムによっているといってよい。

主要な作物である野菜について，作物別の栽培延面積 (同一の施設を年間反復使用する場合の合計面積)をみ ると図 3 のとおりで, 昭和50（1975）年以降は, 従来施 設利用などの考えられなかった，野菜類（「その他」と して分類されて来た）の，施設での栽培が急增し，従来 主流とされて来た，トマト・イチゴ・キュウリなどは， 
停滞気味であるということができる。その理由は，後述 する様に，ブラスチックフィルムの各種性能が向上した こと、「その他」野菜を、季節の変り目に，なるべく暖 房をしないか少くして（雨除けなど），生産䚉をかけず に栽培する産地の增したこと，キュウリほかの果菜類は、 収獾労力などの点で，これ以上の拡張がすずかしいこと などのためと考えられている。しかし図 4 に示すように

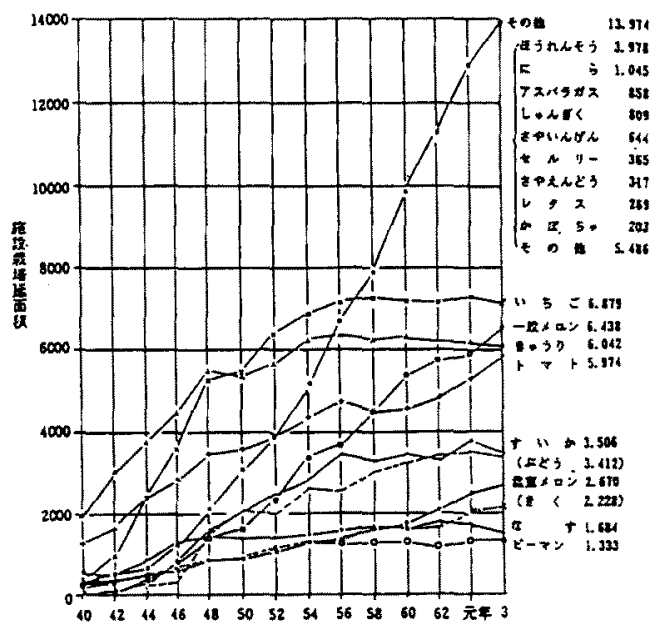

図 3 施設野菜の品目別栽培延面積の推移（单位：ha）

資料：農林水産省食品流通局「園芸用ガラス等・八ウス 等の設䈯状況」
これらの主要野菜では，施設栽培・トンネル栽培の比率 が高く，プラスチック類が古くからの露她中心であっだ 生産様式を変えた事が示されている。

\section{4. 施設資材の区分と使用の状況}

現在，施設園芸で使用されている被㠅資材を，用途・ 用法別に示すと，図5のと抢りであり，これらを原料関 連図で整理すると，图6のと拈りである。

図 5 に示すように，プラスチックフィルムには，軟質 フィルム・硬質フィルム・硬質板などがあり，被䇱材と

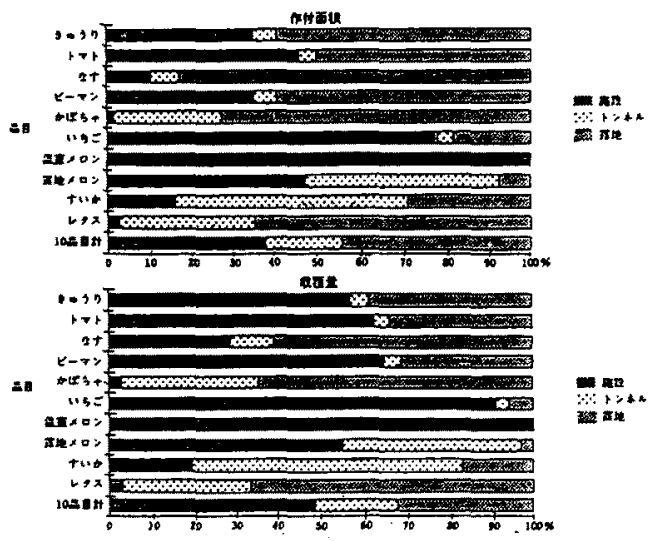

图4野菜全体に上める施設野菜の割合 (平成元年度)

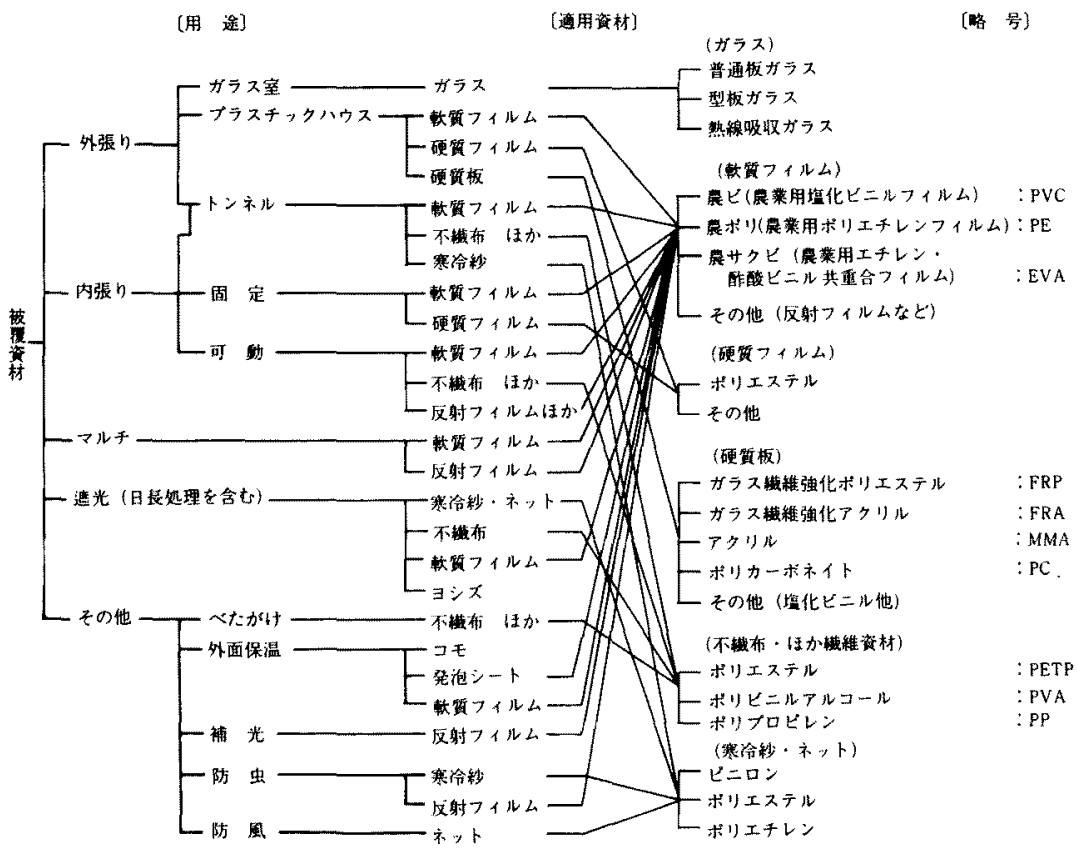

图 5-(1) 被稪資材の区分（内藤'87年より) 
しての用途に応して使い分けられているが，その内容は， 宸ビフィルムか $85 \%$ と压倒的に多く，他を引き離してい る。

被覆資材は，一般に施設の外側に展張される(外張 り）が，更に保温性老高奶ために，八ウス内に展張さ れる (内張り)ことも多く，その用途に応して様々な特 性を持つことが求められている。その結果，各メーカー は競って独自の特性を持つ（と称する）商品を上市して おり，現在市眅される銘柄の数は $300 を$ 越えると報ぜら れている。

被覆資材を用途に応じて選択し，有效に使用する場合 には，その特性をよく理解して使い分ける必要があるが， 求めら机万特性は，一般に光学的特性，熱に関する特性， 水・湿度に関する特性，機械的特性，耐候性の五つに大 別される。これらの特性が必要とされる程度を, 用途別
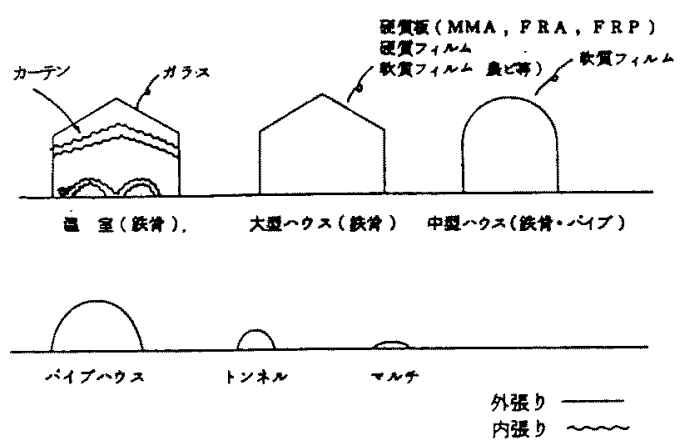

図 5-(2) 被覆形態
に整理すると，表しの様になる。これらは，施設栽培が 行われる季節，地域，溨培する作物の種類によって，そ

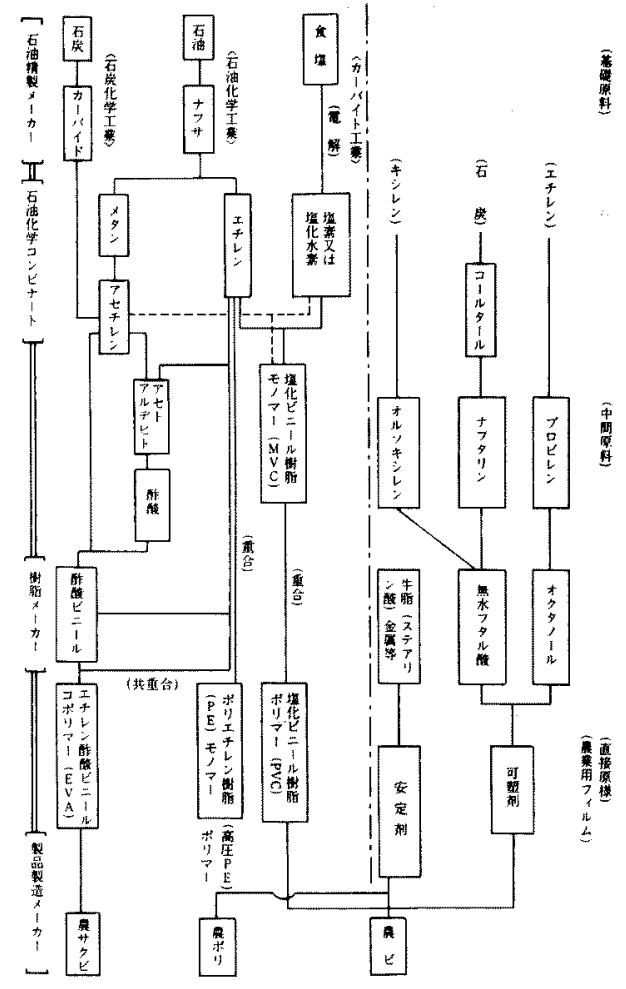

図 6 啀整用フィルムの原料関連汹

表 1 用途別被覆資材に要求己れる特性（総括）

\begin{tabular}{|c|c|c|c|c|c|c|c|c|c|c|c|c|c|c|c|c|}
\hline \multirow{4}{*}{ 用 } & \multirow{4}{*}{ 梌 } & \multicolumn{4}{|c|}{ 光学的特性 } & \multicolumn{3}{|c|}{ 热に関寸る特性 } & \multicolumn{3}{|c|}{ 来・湿度に閣する特性 } & \multicolumn{4}{|c|}{ 機械的特件 } & \multirow{4}{*}{$\begin{array}{l}\text { 酎 } \\
\text { 㑨 } \\
\text { 性 }\end{array}$} \\
\hline & & 透 & 波透 & 癄 & 散 & 保 & 断 & 通 & 新 & 阹 & 透 & 展 & 開 & 伸 & 演 & \\
\hline & & 過 & 接過 & 光 & 光 & 温 & 熟 & 気 & rx & 䈷 & 混 & 淢 & 网 & 艄 & & \\
\hline & & 性 & 剔性: & 性 & 性 & 性 & 性 & 性: & 性: & 性 & 性 & 性 & 性: & 性 & 度 & \\
\hline 外 & 温 空 & - & - & - & 0 & 0 & - & - & - & $\theta$ & - & $\bullet$ & $\ominus$ & 0 & - & 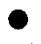 \\
\hline \multirow{2}{*}{$\begin{array}{c}\text { 張 } \\
b\end{array}$} & トンネル & $\bullet$ & - & - & 0 & 0 & - & 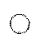 & $\theta$ & - & - & 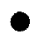 & - & - & 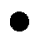 & $\Theta$ \\
\hline & 涑よ博 & $\bullet$ & $\Leftrightarrow$ & - & - & - & - & - & - & - & - & $\ominus$ & - & - & - & $\bullet$ \\
\hline \multirow{2}{*}{$\begin{array}{c}\text { 防 } \\
\text { 张 } \\
b\end{array}$} & 固等 & - & - & - & - & 0 & - & - & - & $\ominus$ & 0 & $\ominus$ & - & 0 & 0 & $\theta$ \\
\hline & iI & $\Leftrightarrow$ & 0 & - & - & - & - & $\ominus$ & $\bullet$ & $\ominus$ & $\ominus$ & $\ominus$ & $\bullet$ & $\bullet$ & 0 & $\theta$ \\
\hline$P$ & ル & - & $\theta$ & - & - & - & 0 & 0 & - & - & - & - & - & - & - & 0 \\
\hline 避 & 光 & - & $\theta$ & $\bullet$ & - & - & $\bullet$ & $\theta$ & $\ominus$ & - & - & $\Theta$ & - & - & 0 & 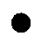 \\
\hline \multicolumn{2}{|c|}{ ハたがけ } & 0 & - & $\theta$ & - & $\ominus$ & $\theta$ & - & - & - & 0 & - & - & - & $\theta$ & - \\
\hline \multirow[t]{4}{*}{ (注) } & 1) & 択に & 。て特 & 二䄇 & すベ & & & 温 & $\cdots カ$ & 又淁 & オ゙ラ & $f \%$ & ウウ & & & \\
\hline & 2) $\theta$ & 同 & 注 & すべ & 特性 & & & & $1+\cdots$ & 觔拿 & fio 2 & 澓 & 60 & & & \\
\hline & $3) 0$ & [ii] & & 晴度 & 587 & & & & x心列 & 架温 & 徨拍 & il & 的 & & & \\
\hline & 3) - & 间 & 考䁖 & しな & $\varepsilon b$. & 特寺 & & & & & & & & & & \\
\hline
\end{tabular}


の程度・内容を異にするが，基本的には，栽培作物の生 育を良好に保って，品質の向上を図ることが目的であり， そのために光線透過率の向上を图ったり，特定波長域を 遮断したりするほか，保温性を高兴とと共に，八ウス内 の植物の生育を阻害する蓩の発生を抑えたり，フイルム の表面（較面）が晨らない样に保つなどの改良が図られ ている。これと同時に，現在のプラスチックフイルムに ついては，広く作業の省力化の可能なことが求められて おり，そのために機械的な強度やフイルムのべなつかな いことも，重要な特性となっている。更に最近の傾向と しては、ハウス内の総合的病害防除の，一端を担い得る 様にするための特性付与も求められ，積極的な籍の発生 抑制，紫外線除去，太陽熟吸収能の向上などといっだ方 向に進みつつある。

最近の被覆資材開発の動向として影著な例をみると， その第一は農ビ（PVC）の内容が著しく多様化しつつあ ることがあって，その一例として従来毎年あるいは 2 年 に一度は張り替えるものとされてきな農ビの中に，数年 という単位での長期使用を唱える製品が登場しつつおる。 又マルチ用農ポリのLーLDPE（リニアー・高压法）化 および多層化，ポりオレフィン系フィルム(镜却しても 塩素が発生しない）の多層化と外張り用への進出（従来 劣るとされてきた保温性や作業性が改善されて)，およ び铤来とは全く原料素材を異にするフイルムの開発など が挙げられて抢り，これらはいずれも，従来加らの施設 園芸の生産様式を変え，新らしい流れを作り出す可能性 のある，高分子化合物であるということができるである j。

电すまでもなくプラスチックの用途は、単にフイルム のみに止まらず，それら他製品の特性やそれらと園芸生 産との関保については，すでに多数の成書の刊行されて いるのか現状であり，本項ですべてをつくすことは不可 能である。しかし農業用プラスチックフイルム類の需要 量は，平成 2 年度で農ビが約 3.8 億 $\mathrm{m}$ ，農ポリが約 5 千t, 農酢ビが約4.7千t（3 者部16.2万t）であるが，農ビは 全販売高の約 3 分の1 占め，必ずしも無視しえない数 值となっており，メーカーの改良への努力もな挍衰えて はいない。にの場合，わが国の全ブラスチック生産量， 即ちはは販売量が，䄪1、200万 $\mathrm{t}$ という大きな数字であ ることを，十分考慮する必要もある。)

\section{5. 施設園芸の問題点と先端技術}

以上に述べた様に，高分子化合物としてのブラスチッ クフイルムの導入は，ある意味では，わが国の野菜生屋 に劇的な変化を引き起こし，周年生産・供給の体制を完 成させた。それは，昭和37（1962）年頃のことであるが，
その後のエネルギー事情の変化（2度にわたる石油ショ ックなど)は，省エネルギー（正しくはエネルギーの効 率的利用）技術の開発を余儀ないものとしたが、その結 果わが国の『プラスチック施設園芸』(以前はビニル園 芸とかハウス園芸といわれた）は，今や世界一の規模を 誇り，オランダ・イギリスのガラス室園芸と並心，独特 の『施設園芸』を成立させるに至った。しかしながら、 最近に拈ける周逊の社会事情・産業事情の变化は，施設 園芸のあり方に，根本的な再検討を迫り，そのための更 なる先端技術の導入を求㤈至っている。その第一は， 農従者の老令化・㣪継者難等に対寸るための，施設の重 装倩化であり，センサー類の導入やコンピュータの利用 等による，八ウス環境の複合自動制御が実現し，专の事 の反動として、「雨除け栽培」等, 極度の簡易栽培様式 を産むという，载培施設の 2 極分化現象が出現している ことであるが、重装備志向は各種省力・自動化装置の整 備やロボットの開発など，先端技術の導入を求めて扔り， その主要な部分として，高分子化合物の利用拡大がある ことは申寸までもない。第二はプラスチックフイルムの 主流が、農ど（PVC）にあることから生ずる，使用ず好 フイルムの処理問題であって，その处理責任の所在や実 施方法の困難はが年毎に切赛の度を加えつつある。PVC は燃焼の際に生ず塩素の直接的毒性や燃焼灯人の被害な どのため、今や全国的なトラブルを巻き起こしつつある。 これら問題への対応は，経済性を問わなければ，現在十 分技術的には可能である由であるが，産業としての農業 の現状を前提とするならば，先端技術の導入による解決 が望ましいのであって，高分子化学での対応としては， 生分解性フイルムの実用化などが，その例として挙げら れている。更に今後のプラスチック類の園芸的利用に当 っては，一方に扔いて，各種作物への利用性の高い沉用 性の付与か望まれ，その反面においては、個別的な作物 の生産を，特異的に助長するフイルムの開発など，冒頭 に述へた特殊な技能的技術の展開を可能にする産品の提 供が求められるなど，高分子化学一の期待には広沉なも のがある。

施設園芸を含め農業とは本来，人間が自らの生活に益 するた如，野生植物を選抜し，長年月を加けて合目的 的に改良（植物に上って洺多くが改要〉した，遗任的 な奇型的形質（人間には有用な）を持つ病的な植物。を， 人間の利用に便なるように生育させる業である。したが って，それらに对しては，人間の生活に益すべく開発さ れた，高分子化学生㦃物の助力が必要であることは，明 らかであるというべきであろう。

(平成 5 年 5 月 25 日受理) 